\title{
QUEEN'S
UNIVERSITY
BELFAST
}

\section{Survival of patients with skin melanoma in Europe increases further: Results of the EUROCARE-5 study}

Crocetti, E., Mallone, S., Robsahm, T. E., Gavin, A., Agius, D., Ardanaz, E., Lopez, M. D. C., Innos, K., Minicozzi, P., Borgognoni, L., Pierannunzio, D., \& Eisemann, N. (2015). Survival of patients with skin melanoma in Europe increases further: Results of the EUROCARE-5 study. European Journal of Cancer, 51(15), 21792190. https://doi.org/10.1016/j.ejca.2015.07.039

\section{Published in:}

European Journal of Cancer

\section{Document Version:}

Peer reviewed version

Queen's University Belfast - Research Portal:

Link to publication record in Queen's University Belfast Research Portal

\section{Publisher rights}

(C) 2015 Elsevier Ltd. This manuscript version is made available under the CC-BY-NC-ND 4.0 license http://creativecommons.org/licenses/bync-nd/4.0/ which permits distribution and reproduction for non-commercial purposes, provided the author and source are cited.

\section{General rights}

Copyright for the publications made accessible via the Queen's University Belfast Research Portal is retained by the author(s) and / or other copyright owners and it is a condition of accessing these publications that users recognise and abide by the legal requirements associated with these rights.

Take down policy

The Research Portal is Queen's institutional repository that provides access to Queen's research output. Every effort has been made to ensure that content in the Research Portal does not infringe any person's rights, or applicable UK laws. If you discover content in the Research Portal that you believe breaches copyright or violates any law, please contact openaccess@qub.ac.uk. 


\section{Survival for skin melanoma in Europe: results of the EUROCARE-5 study.}

Emanuele Crocetti $^{\mathrm{a}, \mathrm{o}}$, Sandra Mallone ${ }^{\mathrm{b}}$, Trude Eid Robsahm ${ }^{\mathrm{c}}$, Anna Gavin ${ }^{\mathrm{d}}$, Domenic Agius ${ }^{\mathrm{e}}$, Eva Ardanaz ${ }^{\mathrm{f}, \mathrm{g}}$, Maria-Dolores Chirlaque Lopez ${ }^{\mathrm{h}, \mathrm{g}}$, Kaire Innos $^{\mathrm{k}}$, Pamela Minicozzi ${ }^{\mathrm{i}}$, Lorenzo Borgognoni $^{1}$, Daniela Pierannunzio ${ }^{\mathrm{b}}$, Nora Eisemann $^{\mathrm{m}}$, and the EUROCARE-5 Working Group ${ }^{\mathrm{n}}$

${ }^{\text {a } U O ~ E p i d e m i o l o g i a ~ C l i n i c a, ~ D e s c r i t t i v a ~ e ~ R e g i s t r i ~-~ I S P O, ~ F i r e n z e, ~ I t a l y ~}$

${ }^{\mathrm{b}}$ Centro Nazionale di Epidemiologia, Sorveglianza e Promozione della Salute, Istituto Superiore di Sanità, Roma, Italy

${ }^{\mathrm{c}}$ Cancer Registry of Norway, Institute of Population Based Cancer Research, Oslo, Norway

${ }^{\mathrm{d}}$ Northern Ireland Cancer Registry, Centre for Public Health, Queens University, Belfast, Northern Ireland

${ }^{\text {e }}$ Malta National Cancer Registry, Department of Health Information and Research

${ }^{\mathrm{f}}$ Navarra Cancer Registry. Navarra Public Health Institute, Pamplona, Spain

${ }^{\mathrm{g}}$ CIBER of Epidemiology and Public Health (CIBERESP), Spain

${ }^{\text {h }}$ Servicio de Epidemiología, Department of Epidemiology, Consejería de Sanidad, Murcia Health Authority, Murcia, Spain

${ }^{\mathrm{k}}$ Department of Epidemiology and Biostatistics National, Institute for Health Development, Tallinn, Estonia

i Analytical Epidemiology and Health Impact Unit, Department of preventive and Predictive Medicine, Fondazione IRCCS Istituto Nazionale dei Tumori, Milan, Italy

${ }^{1}$ SC Chirurgia Plastica e Ricostruttiva, Ospedale S.M. Annunziata - Azienda Sanitaria di Firenze Centro di Riferimento Regionale per il Melanoma, Istituto Toscano Tumori, Firenze, Italy ${ }^{\mathrm{m}}$ Institute of Cancer Epidemiology, University of Luebeck, Luebeck, Germany

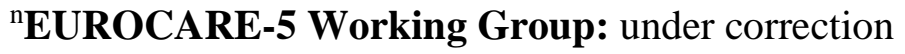


${ }^{\mathrm{o}}$ corresponding author: UO Epidemiologia Clinica, Descrittiva e Registri, ISPO, Via delle Oblate 2,

50141, Florence, Italy. Tel: +390557972508, e-mail: e.crocetti@ ispo.toscana.it

\section{Sources of support (grants):}

The Compagnia di San Paolo, the Fondazione Cariplo Italy, the Italian Ministry of Health (Ricerca Finalizzata 2009, RF-2009-1529710) and the European Commission (European Action Against Cancer, EPAAC, Joint Action No20102202). 


\begin{abstract}
Background

In Europe skin melanoma (SM) survival has increased over time but differences between countries and areas of Europe remain.
\end{abstract}

\title{
Methods
}

We calculated European relative survival estimates and geographical comparisons for 241,485 cases of invasive SM, in ages 15 years and over, diagnosed in Europe (2000-2007), with survival time trends estimated using the period approach during 1999-2007, for 213,101 cases.

\section{Results}

In Europe, estimated 5-year relative survival was $83.2 \%$ (95\% confidence interval, CI $82.9 \%$ $83.6 \%)$. The highest values were in Northern $(87.7 \% ; 87.2 \%-88.2 \%)$ and Central $(87.6 \% ; 87.2 \%-$ $88.0 \%)$ Europe, followed by Ireland and UK (85.6\%; 85.2\%-86.0\%) and Southern Europe (82.6\%; 82.1\%-83.2\%). The lowest survival estimate was in Eastern Europe (74.3\%; 73.6\%-75.1\%). Within regions the inter-country absolute difference in percentage points of survival varied from $3.9 \%$ in Northern to $33.8 \%$ in Eastern Europe. Relative survival decreased markedly with age and was higher in women than men. Differences according to SM morphology and skin sub-sites also emerged. Survival has slightly increased from 1999 to 2007, with a small improvement in Northern and the most pronounced improvement in Eastern Europe.

\section{Discussion}

SM survival is high and still increasing in Europe. The gap between Northern and Southern and especially Eastern European countries, although still present, diminished over time. Differences in early detection practices may presumably explain most of the geographical differences, better survival in women and in younger ages. However, part of the improvement in survival may be attributed to overdiagnosis.

Key-words: EUROCARE, skin melanoma, cancer survival, registries, European populations 


\section{Introduction}

Skin melanoma (SM) incidence has increased sharply in most Western-type countries over the last decades; a trend that continues [1]. In 2012, SM ranked seventh among the most frequently diagnosed cancers in the European Union, 3.2\% of all new cancers (all ages, both sexes). [2] The main known modifiable risk factor for SM is intermittent ultraviolet radiation exposure (UV). Therefore, the rise in incidence has been presumably driven by increased leisure exposure to UV radiation from sun and indoor tanning [3].

Mortality rates are still increasing in many European countries (e.g. Ireland, Sweden, Netherlands, etc.) $[2,4]$ and they are nearly stable in others (e.g. Austria, Denmark, Croatia, Czech Republic, etc.) $[2]$.

According to previous EUROCARE studies, SM relative survival (RS) has increased over time [5]; SM ranks fourth among cancers with the best survival in Europe [6].

However, survival varies markedly between and within European regions with only a slight decrease in geographical differences seen over time [5]. Survival also varies across age groups and between sexes.

The main prognostic factor for SM is stage at diagnosis (Breslow thickness) [7] and prompt and appropriate treatment. Therefore, in many countries a lot of effort is put in early diagnosis. However, improvements in survival do not necessarily reduce mortality [8]. In fact, overdiagnosis and lead time bias affect survival without preventing deaths. Therefore, differences and changes in survival must be interpreted with caution.

The aim of the present EUROCARE-5 study is to provide updated data on SM RS, focusing on differences still present across European countries.

\section{Materials and methods}


We considered all adult patients (15 years and over) diagnosed in 2000-2007, with one or multiple invasive SM, which was defined by topography (C44.0-C44.9) and morphology (8720-8790) codes, according to the International Classification of Diseases for Oncology, (ICDO-3) [9].

Overall, 241,485 cases from 29 countries (86 cancer registries [CRs]), divided into five European regions (Ireland and UK [Ireland/UK], Northern, Central, Southern and Eastern Europe), and followed up to the end of 2008 were included in the analyses.

We estimated the age-specific (15-44, 45-54, 55-64, 65-74, and 75+ years) and age-standardised 1year, 5-year and 5-year relative survival conditional to surviving 1 year after diagnosis.

We also presented the 5-year RS for different morphology and topography subgroups. In particular, we considered 5 morphology subgroups: superficial spreading (SSM, ICDO-3 code 8743), lentigo malignant (8742), nodular melanoma (8721), other specified types (8722-3, 8730, 8740-1, 8744-6, 8761, 8770-4, 8780) and not otherwise specified (NOS, 8720) SM; and 4 topography groups: head and neck (C44.0-C44.4), trunk (C44.5), limbs (C44.6-C44.7), overlapping and not specified sites (C44.8, C44.9).

Age-standardised incidence rates were also computed.

We also analysed trends in 5-year RS over 1999-2001, 2002-2004, and 2005-2007, involving 213,101 cases from the 65 CRs with complete incidence data from at least 1996 to 2006, with the exception of 16 CRs from France and Spain with data from 1995 to 2004.

\section{Statistical methods}

Data collection, quality checks process and statistical methods of the EUROCARE project were described elsewhere in this monograph [10]. In brief, RS for cases diagnosed in 2000-2007 was estimated by the complete cohort approach [11] and for time trends analyses the period approach [10.12] was applied. The Z-test [10] was used to compare survival estimates over the study period. European survival estimates derived from the cohort analyses were country-weighted; whereas estimates in the trend analysis were area-weighted [10]. 
Both age-specific and age-standardised [13] RS were obtained by using the Ederer II method for expected survival [14], whereas incidence rates were age-standardised on the European standard population.

The Pearson's correlation coefficient [15] was computed between age-standardised incidence rates and age-standardised five-year RS for the period 2000-2007, by European region.

Finally, only the 51 out of 86 CRs with adequate morphology completeness (i.e. proportion of NOS $\mathrm{SM}<30 \%$ ) were included in the survival analyses for cases diagnosed in 2000-2007.

\section{Results}

The EUROCARE-5 database collected 243,417 SM diagnosed in 2000-2007 (Table 1). Cases with major errors, known only from death certificate (DCO), or known from autopsy alone were excluded from the survival analyses. The proportion of major errors was $0 \%$ or negligible for the majority of the registries but 5\% in Cracow (Poland). Moreover, the proportions of DCO and autopsy cases were, respectively, low $(0.4 \%$; range $0.0 \%-2.7 \%)$ or negligible $(0.04 \%$; range $0.0 \%$ $0.5 \%$ ). After exclusions, 241,485 cases were included in the analyses. The proportion of microscopically verified cases was $98.5 \%$ (range $87.5 \%-100 \%$ ).

Overall Europe, $15.4 \%$ of analysed SM were located on the head and neck (range 12.9\%, Southern Europe $-18.5 \%$, Ireland/UK), $32.6 \%$ on the trunk (27.2\%, Ireland/UK - 40.6\%, Eastern Europe), $44.3 \%$ on the limbs (36.6\%, Southern Europe $-49.3 \%$, Ireland/UK) and $7.7 \%$ on not specified (or overlapping) sites (4.9\%, Ireland/UK - 19.1\%, Southern Europe) (Table 2).

Considering all the 86 analysed CRs, the proportion of cases with morphology NOS was $38.6 \%$ (Table 1), ranging from 5.7\% (Biella, Italy), 6\% (Doubs, France) to 93.7\% (Poland, Cracow), 96.8\% (Croatia), 99.0\% (Poland, Silesia) and 99.6\% (Finland). Thus, not all the CRs made available detailed information for the requested variable. Among the 51 CRs with complete information on morphology (99068 cases), more than half of cases presented a SSM, whereas only $6 \%$ of cases the lentigo maligna. Morphology distribution was quite homogeneous among European regions, except 
for Eastern Europe showing the lowest proportion of SSM (34.7\%) and the highest proportion of cases with morphology NOS (23.7\%) (Table 2).

The 5-year age-standardised RS for Europe was 83.2\% (95\% confidence interval, CI 82.9\%-83.6\%) ranging from $87.7 \%$ (95\%CI 87.2\%-88.2\%) in Northern to $74.3 \%$ in Eastern (95\% CI $73.6 \%$ 75.1\%) Europe (Figure 1). Survival estimates varied markedly among Eastern European countries but were relatively high and homogeneous in the other regions. The absolute difference between the highest and lowest survival value was 4.2 percentage points (4.2\%) in Northern Europe, $7.3 \%$ in Central Europe, $10.7 \%$ in Ireland and UK, 17.2\% in Southern Europe and 33.8\% in Eastern Europe where almost all countries had low survival with the exception of Czech Republic (83.4\%).

One-year RS was 95.1\%, with the same - but less evident - ranking across countries than 5-year RS, 97.4\% in Northern and 91.5\% in Eastern Europe.

Patients who survived one year since diagnosis had a slightly better 5-year RS than those at the time of diagnosis (87.5\% vs. $83.2 \%$, European average). This improvement was quite small and homogeneous in Northern, Central Europe and Ireland and UK (around +3 percentage points) while it was higher in Southern $(+4.8 \%)$ and Eastern $(+6.9 \%)$ Europe.

The correlation coefficient between age-standardised survival and incidence rate was high (0.7), i.e. high incidence often coincided with high survival.

Overall Europe, RS was significantly higher in women than in men: the absolute difference in RS between women and men was $+2.2 \%$ at 1 year after diagnosis, $+5.9 \%$ at 3 years and $+7.4 \%$ at five years (Figure 1). Same results were evident for all age groups (Figure 1) and each European region. Differences in 5-year RS between sexes were quite stable across Europe, ranging from 5.5\% in Central Europe to $8.6 \%$ in Ireland and UK (data not shown).

Moreover, five-year RS decreased with advancing age, from $89.5 \%$ for patients aged $15-44$ years, to $85.4 \%$ in the age group $45-54$ years, $83.6 \%$ for $55-64$ years, $80.0 \%$ for $65-74$ years and $72 \%$ for $75+$ years old. 
As regards morphology, the highest survival was observed in Europe for lentigo malignant (98.4\%, range $97.2 \%-99.7 \%)$, followed by SSM (94.7\%; 92.8\%-95.0\%), SM NOS (78.2\%; 60.8\%-82.7\%), other SM (76.5\%; 70.5\%-80.4\%) and then nodular (70.0\%; 63.8\%-70.1\%) (Figure 2a).

Among specified morphologies, the 5-year RS for nodular and other SM in Eastern Europe was worse than the European average. Women had better survival for all morphologies (Figures 2b-c).

Five-year RS estimates for skin sub-sites in Europe were: $84.9 \%$ for limbs (95\% CI 73.8\%-85.4\%), $80.6 \%$ for trunk (95\% CI $73.8 \%-81.2 \%), 80.3 \%$ for head and neck (95\% CI $73.8 \%-81.4 \%$ ), and 64.9\% for overlapping and unspecified sites (95\% CI 63.9\%-66.0\%). Eastern Europe showed worse survival for all sub-sites (Figure 3a). However, we found that survival was generally better for women than for men for all sub-sites (Figures 3b-c).

Figure 4 shows trends in 5-year age-adjusted RS. In Europe, there was a slight improvement from $82.4 \%$ in $1999-2001$ to $85.2 \%$ in the most recent period $(\mathrm{p}<0.001)$. The absolute difference in survival estimates between 2005-2007 and 1999-2001 was 0.8\% ( $\mathrm{p}=0.08)$ for Northern Europe, $2.3 \%$ for Central $(p<0.001)$ and Southern Europe $(p=0.01), 3.1 \%$ for Ireland and UK $(p<0.001)$ and $5 \%$ for Eastern Europe $(\mathrm{p}<0.001)$.

\section{Discussion}

The present study provided survival estimates based on the widest SM dataset ever published in the EUROCARE project.

Five-year RS for SM in Europe was high, 83.2\%. Among the analyzed European regions, the best survival was found in Northern and Central Europe, then in Ireland and UK and in Southern Europe; Eastern Europe had the lowest survival. Areas with the best survival had the lowest intercountry variability while Eastern Europe presented the highest variability.

These findings confirmed previously documented geographical differences [16].

SM survival is strongly related to the stage (Breslow thickness) at diagnosis [7]. Thinner SM have a better prognosis than thicker ones. Therefore, part of the geographical differences may be caused by 
different stage distribution at diagnosis. Early detection and population awareness on skin selfexamination promote the detection of thinner SM.

Unfortunately, information of stage is not available in the present study. However, a poorer distribution for Breslow's thickness has been already document in Eastern countries in comparison with Northern and Western countries [17]. Moreover, the 1-year RS was lower in Eastern Europe than in other regions, which indicated a larger proportion of SM with late stage at diagnosis [18].

The close relationship between Breslow's thickness and prognosis legitimized those who support early diagnosis [19-20]. However, a favourable survival does not necessarily indicate low mortality. There is little evidence about the effectiveness of SM screening on mortality [21-24] and no results from randomized trials evaluating mortality reduction are to be expected $[22,25]$.

Despite the few indications for positive screening effectiveness from observational studies, an improvement in survival may be at least partially apparent due to a side effect of early diagnosis named overdiagnosis $[8,26]$. This means the detection of tumours that for their nature (indolent, regression, etc.) or for the combination of their nature and the age of the patient would have not become clinically evident during the life of the patient [27]. The strong relationship between the increase in biopsy rate and the incidence of SM has been proposed as a clue for overdiagnosis [28] and, although at least part of the growth in incidence is true [29] - considering also the increase in mortality [2,4] - overdiagnosis is contemplated as the main explanation for the rise in trends [30].

Therefore, differences in early diagnosis patterns could explain some of the variability in SM survival in Europe. The strong correlation evidenced between SM incidence and survival supports this hypothesis.

Other explanations could contribute to the differences in survival, such as different socioeconomic status, which has been shown to be an independent prognostic factor [31]. In addition, also treatment differences could be involved. For example, differential use of new expensive drugs could become more important for SM diagnosed in more recent years, due to the availability of BRAF or MEK inhibitors and anti-CTLA4 monoclonal antibodies [32]. 
We also found a relationship between survival and SM morphology (worse survival for nodular SM and for NOS SM in Eastern Europe) and topography (worse survival for NOS and overlapping sites). Interpretation of SM with NOS morphology or site is difficult. As regards morphology, our data showed, in all the countries out of Eastern Europe, intermediate survival for NOS SM. Therefore, in these regions NOS seemed to represent a 'sample' of all the morphology types. On the contrary, in Eastern Europe, morphology NOS had the worst prognosis. In this case NOS seemed to be a proof for cases selection, e.g. patients with advanced stage at diagnosis or older ones, etc.

In all the analysed regions survival for SM with NOS site was worse than for specified sites.

Moreover, a geographical variation in the case-mix by morphology sub-groups could contribute to explain at least some of the geographical differences observed in survival. However, survival in Eastern Europe for nodular, other types and NOS SM, was lower than the European average suggesting again the role of stage at diagnosis (possibly mediated by socioeconomic status, or treatment differences).

Sex has been confirmed [33] to be a strong survival predictor with better prognosis for women. The difference in relative survival between women and men was already present within the 1-year after diagnosis and increased over time. Women had better survival across all ages, skin sub-sites and morphologies. A better stage distribution at diagnosis has been suggested as a possible explanation [31] due to the supposed greater attention of women than men to their body and health. Moreover, an independent effect of female sex, supporting yet unknown biological factors, has also been suggested [34].

The present study confirmed that SM RS decreased with increasing age of the patients. Also the effect of age was presumably mediated by thickness at diagnosis [35] as a different amount of early diagnosis across generations.

Five-year RS has improved over time, in all the areas and especially in Eastern countries. The survival levels in Northern and Central Europe were probably approaching a plateau considering the slowing down of the improvement during the last period of time. 
The EUROCARE standardized protocol reassured about the quality and comparability of analyzed data [36]. The quality of the database has been addressed in another chapter of this monograph [10]. However, although it is straightforward to interpret clearly an indicator of low quality, e.g. high proportion of patients lost to follow-up, it is more difficult to understand very high values of a quality index, e.g. $0 \%$ DCO or $100 \%$ microscopy verification. Also to infer the quality of histology reporting on the basis of the details in morphological entities definition may be fallacious; this could be the case of Denmark for which no detailed morphology codes have been made available for this study [35].

Due to increased incidence and higher survival, the number of people with a history of SM has risen in the European populations. In 2010, more than 1,000,000 European citizens were estimated to have had a previous SM diagnosis [37]. The increase in incidence and the improvement in survival will boost the number of prevalent SM patients in all the European countries.

In conclusion, the heterogeneity in SM survival in Europe shows the need for the improvement in diagnostic activity in the Eastern countries, which all (except for Bulgaria) also have SM mortality rates higher than the European average [2]. The range of theoretical improvement is wide, in fact, there are more than 13 percentage points of differences in 5-year RS from Eastern to Northern or Central European Countries. Skin melanoma control and prevention should consider the possible overdiagnosis evaluating the improvement in survival together with those in mortality and incidence [38]. Moreover, primary prevention should match secondary prevention programs. 


\section{Acknowledgements}

We thank Chiara Margutti, Simone Bonfarnuzzo and Camilla Amati for secretarial assistance.

\section{Role of funding source}

The study was funded by the Compagnia di San Paolo, the Fondazione Cariplo Italy, the Italian Ministry of Health (Ricerca Finalizzata 2009, RF-2009-1529710) and the European Commission (European Action Against Cancer, EPAAC, Joint Action No20102202). The funding sources had no role in study design, the collection, analysis or interpretation of data, the writing of the report, or the decision to submit the article for publication. 


\section{References}

[1] Erdmann F, Lortet-Tieulent J, Schüz J, Zeeb H, Greinert R, Breitbart EW, et al. International trends in the incidence of malignant melanoma 1953-2008--are recent generations at higher or lower risk? Int J Cancer. 2013;132:385-400.

ECO,

European

Cancer

Observatory:

ttp://eco.iarc.fr/EUCAN/Country.aspx ?ISOCountryCd=930 accessed 4th September 2014.

[3] Wehner MR, Chren MM, Nameth D, Choudhry A, Gaskins M, Nead KT, Boscardin WJ, et al.. International prevalence of indoor tanning: a systematic review and meta-analysis. JAMA Dermatol. 2014;150:390-400.

[4] Hollestein LM, van den Akker SAW, Nijsten T, Karim-Kos HE, Coebergh JW \& de Vries E. Trends of cutaneous melanoma in The Netherlands: increasing incidence rates among all Breslow thickness categories and rising mortality rates since 1989. Annals of Oncology 2012;23: 524-30.

[5] Sant M, Capocaccia R, Coleman MP, Berrino F, Gatta G, Micheli A, et al. Cancer survival increases in Europe, but international differences remain wide.Eur J Cancer. 2001;37:1659-67.

[6] De Angelis R, Sant M, Coleman MP, Francisci S, Baili P, Pierannunzio D, et al. Cancer survival in Europe 1999-2007 by Country and age: results of EUROCARE-5 - a population-based study Lancet Oncol 2014; 15: 23-34.

[7] Balch CM, Soong SJ, Atkins MB, Buzaid AC, Cascinelli N, Coit DG, et al. An evidence-based staging system for cutaneous melanoma. CA Cancer J Clin. 2004;54:131-49.

[8] Cho H, Mariotto AB, Schwartz LM, Luo J, Woloshin S. When do changes in cancer survival mean progress? The insight from population incidence and mortality. J Natl Cancer Inst Monogr. 2014;49:187-97.

[9] Fritz AG, Percy C, Jack A, et al, eds. International Classification of Diseases for Oncology (ICD-O). 3rd edn. Geneva: World Health Organization, 2000.

[10] Rossi S. Database and Methods Database and Methods EJC 2015 TO BE DEFINED 
[11] Brenner H, Gefeller O, Hakulinen T. Review. Period analysis for 'up-to-date' cancer survival data: theory, empirical evaluation, computational realisation and applications. Eur $\mathrm{J}$ Cancer. 2004;40:326-35.

[12] Brenner H, Hakulinen T. Up-to-date long-term survival curves of patients with cancer by period analysis. J Clin Oncol 2002;20:826-32.

[13] Corazziari I, Quinn M, Capocaccia R. Standard cancer patient population for age standardising survival ratios. Eur J Cancer. 2004;40:2307-16.

[14] Ederer F, Heise H. Instructions to IBM 650 programmers in processing survival computations. Methodological note no. 10. Bethesda, MD: End Results Evaluation Section, National Cancer Institute; 1959.

[15] Pearson, K. Mathematical contributions to the theory of evolution-III. Regression, heredity, and panmixia. Philosophical Transactions of the Royal Society of London, Series A 1896; 187: $253-318$.

[16] Coleman MP, Gatta G, Verdecchia A, Estève J, Sant M, Storm H, et al. EUROCARE-3 summary: cancer survival in Europe at the end of the 20th century. Annals of Oncology 2003;14: v128-v149.

[17] de Vries E, Boniol M, Doré JF, Coebergh JW; EUROCARE working group.Lower incidence rates but thicker melanomas in Eastern Europe before 1992: a comparison with Western Europe.Eur J Cancer. 2004;40:1045-52.

[18] Sant M, Allemani C, Santaquilani M, Knijn A, Marchesi F, Capocaccia R, et al. Eur J Cancer 2009;45:931-91.

[19] Geller AC, Swetter SM, Oliveria S, Dusza S, Halpern AC. Reducing mortality in individuals at high risk for advanced melanoma through education and screening. J Am Acad Dermatol 2011;65:s87-94. 
[20] Mayer JE, Swetter SM, Fu T, Geller AC. Screening, early detection, education, and trends for melanoma: Current status (2007-2013) and future directions: Part II. Screening, education, and future directions. J Am Acad Dermatol. 2014;71:611.e1-611.e10.

[21] Schneider JS, Moore DH 2nd, Mendelsohn ML.Screening program reduced melanoma mortality at the Lawrence Livermore National Laboratory, 1984 to 1996. J Am Acad Dermatol. 2008;58:741-9.

[22] Aitken JF, Elwood JM, Lowe JB, Firman DW, Balanda KP, Ring IT. A randomised trial of population screening for melanoma. J Med Screen. 2002;9:33-7.

[23] Swetter SM, Pollitt RA, Johnson TM, Brooks DR, Geller AC. Behavioral determinants of successful early melanoma detection: role of self and physician skin examination.Cancer. 2012;118:3725-34.

[24] Katalinic A, Waldmann A, Weinstock MA, Geller AC, Eisemann N, Greinert R, et al. Does skin cancer screening save lives?: an observational study comparing trends in melanoma mortality in regions with and without screening. Cancer. 2012;118:5395-402.

[25] Aitken JF, Elwood M, Baade PD, Youl P and English D. Clinical whole-body skin examination reduces the incidence of thick melanomas. Int. J. Cancer. 2010;126:450-458.

[26] Glusac EJ. The melanoma 'epidemic': lessons from prostate cancer. J Cutan Pathol. 2012;39:17-20.

[27] Curiel-Lewandrowski C, Kim CC, Swetter SM, Chen SC, Halpern AC, Kirkwood JM, et al. Melanoma Prevention Working Group-Pigmented Skin Lesion Sub-Committee Survival Is Not the Only Valuable End Point in Melanoma Screening Journal of Investigative Dermatology. 2012;132:1332-7.

[28] Welch HG, Woloshin S, Schwartz LM. Skin biopsy rates and incidence of melanoma: population based ecological study. BMJ, 2005;331:481. 
[29] Stefansson H1, Tryggvadottir L, Olafsdottir EJ, Mooney E, Olafsson JH, Sigurgeirsson B, et al. Cutaneous melanoma in Iceland: changing Breslow's tumour thickness. J Eur Acad Dermatol Venereol. 2015;29:346-52.

[30] Welch HG, Black WC. Overdiagnosis in Cancer. J Natl Cancer Inst 2010;102:605-13.

[31] Eriksson H, Lyth J, Månsson-Brahme E, Frohm-Nilsson M, Ingvar C, Lindholm C, et al. Low level of education is associated with later stage at diagnosis and reduced survival in cutaneous malignant melanoma: a nationwide population-based study in Sweden. Eur J Cancer. 2013;49:270516.

[32] Eggermont AM, Spatz A, Robert C. Cutaneous melanoma. Lancet. 2014;383:816-27.

[33] Sant M, Aareleid T, Berrino F, Bielska Lasota M, Carli PM, Faivre J, et al.EUROCARE-3: survival of cancer patients diagnosed 1990-94--results and commentary. Ann Oncol. 2003;14:v61118.

[34] Joosse A, de Vries E, Eckel R, Nijsten T, Eggermont AMM, HÖlzel D, et al. Gender Differences in Melanoma Survival: Female Patients Have a Decreased Risk of Metastasis. Journal of Investigative Dermatology. 2011;131, 719-26.

[35] Bay C, Kejs AM, Storm HH, Engholm G. Incidence and survival in patients with cutaneous melanoma by morphology, anatomical site and TNM stage: A Danish Population-based Register Study 1989-2011. Cancer Epidemiol. 2015;39:1-7

[36] De Angelis R, Francisci S, Baili P, Marchesi F, Roazzi P, Belot A, et al. The EUROCARE-4 database on cancer survival in Europe: data standardisation, quality control and methods of statistical analysis. Eur J Cancer. 2009;45:909-30.

[37] Gatta G, Mallone S, van der Zwan JM, Trama A, Siesling S, Capocaccia R, et al. Cancer prevalence estimates in Europe at the beginning of 2000.Ann Oncol. 2013;24:1660-6.

[38] Karim-Kos HE, Kiemeney LALM, Louwman MWJ, Coebergh JWW, de Vries E. Progress against cancer in the Netherlands since the late 1980s: An epidemiological evaluation. Int. J. Cancer. 2012 130: 2981-9. 
Figure 1. Age-specific and age-standardised relative survival for skin melanomas diagnosed in 2000-2007, by European region, country, gender and overall.

\section{EUROPE, adults diagnosed 2000-2007}

Age-standardized 1-yr, 5-yr relative survival (95\% confidence interval) and at 5-yr conditional on surviving 1 year

\begin{tabular}{|c|c|c|c|c|c|c|c|c|c|c|}
\hline \multirow[b]{2}{*}{ Northern Europe } & \multirow{2}{*}{$\begin{array}{r}\begin{array}{r}\text { Number } \\
\text { of cases }\end{array} \\
40,597\end{array}$} & \multicolumn{3}{|c|}{ One year } & \multicolumn{3}{|c|}{ Five years } & \multicolumn{3}{|c|}{ Conditional } \\
\hline & & 97.41 & $97.2-$ & 97.5) & 87.71 & 87.2 - & 88.2) & 90.11 & 89.6 - & $-90.6)$ \\
\hline Denmark & 9.854 & 97.01 & $96.5-$ & 97.4) & 87.81 & 86.7 - & 88.9) & 90.51 & $89.5-$ & $-91.6)$ \\
\hline Finland & 6.208 & 95.8( & $95.3-$ & 96.5) & 85.3( & $84.1-$ & 86.6) & 89.0( & $87.8-$ & $-90.2)$ \\
\hline Iceland & 404 & 96.6( & $94.2-$ & 99.0) & 85.0( & $79.2-$ & 91.2) & 88.0( & $82.4-$ & - 93.9$)$ \\
\hline Nonway & 8.575 & 97.1( & 96.7 - & 97.6) & 88.4( & 85.4 & 87.5) & 89.01 & $87.8-$ & $-90.0)$ \\
\hline Sweden & 15,755 & 98.3( & 98.0 & 88.6) & 89.2( & $88.5-$ & 90.0) & 80.8( & 90.1 - & - 91.5$)$ \\
\hline Ireland and UK & 75,761 & 96.21 & $96.0-$ & $96.3)$ & 85.61 & $85.2-$ & $86.0)$ & 89.01 & $88.6-$ & - 89.4$)$ \\
\hline Ireland & 4.451 & 96.8( & $96.3-$ & 97.6) & 86.4( & $84.9-$ & $88.0)$ & 89.21 & $87.7-$ & - 90.7$)$ \\
\hline UK, England & 59.155 & 96.1( & $96.0-$ & 96.3) & 85.3( & $84.8-$ & 85.8) & 88.8( & $88.4-$ & $-89.2)$ \\
\hline UK, Northern Ireland & 1.822 & 97.51 & $96.6-$ & 88.5) & 90.7( & $88.5-$ & 93.1) & 83.0 & $90.8-$ & $-95.3)$ \\
\hline UK, Scotland & 6.774 & 97.0( & $96.5-$ & 97.5) & 88.8( & $87.6-$ & 90.1) & 81.5( & 90.4 & - 92.7$)$ \\
\hline UK, Wales & 3,559 & 93.8( & $92.8-$ & 84.7) & 80.0( & $78.2-$ & 81.8) & 85.4( & $83.6-$ & - 87.1) \\
\hline Central Europe & 68,765 & 96.81 & $96.6-$ & $96.9)$ & 87.61 & $87.2-$ & $88.0)$ & 90.51 & $90.2-$ & - 90.9$)$ \\
\hline Austria & 8.543 & 91.7( & 91.1- & 92.3) & 83.11 & $82.0-$ & $84.2)$ & 90.8( & $89.8-$ & $-81.6)$ \\
\hline Belgium & 6.202 & 96.2( & 95.7. & 96.8) & 83.4( & 82.1 - & 84.8) & 88.7( & 85.4 & $-88.0)$ \\
\hline France & 4.292 & 97.8( & $97.3-$ & 88.4) & 87.2( & $85.8-$ & 88.5) & 89.1( & $87.8-$ & - 90.4$)$ \\
\hline Germany & 21,043 & 97.1( & $96.8-$ & 97.4) & 89.4( & 88.7 . & 90.1) & 82.11 & 91.4- & - 92.7$)$ \\
\hline Switzerland & 4,131 & 98.31 & 97.8 - & 88.8) & 90.4( & 89.0 - & 91.8) & 82.01 & $90.8-$ & - 93.3$)$ \\
\hline The Netherlands & 24,554 & 98.0( & $97.8-$ & 98.3) & 88.4( & 87.7 - & 89.1) & 90.21 & $89.5-$ & - 90.8$)$ \\
\hline Southern Europe & 30,806 & 94.61 & $94.3-$ & 94.9) & 82.61 & 82.1 - & 83.2) & 87.41 & $86.8-$ & - 87.9$)$ \\
\hline Croatia & 3.812 & 84.91 & 83.7 - & 86.1) & 70.8( & $68.8-$ & 72.7) & 83.2( & 81.1 - & $-85.3)$ \\
\hline Italy & 17.813 & 96.4( & 96.1 - & 96.7) & 85.4( & 84.7 - & 86.1) & 88.8( & $88.0-$ & - 89.3$)$ \\
\hline Maita & 275 & 98.6( & $96.5-$ & 100.8) & 87.8( & 81.1. & 85.0) & 89.0( & $82.5-$ & $-96.0)$ \\
\hline Portugal & 3,168 & 93.61 & 92.7 . & 94.6) & 80.31 & $78.5-$ & 82.2) & 85.8( & 84.1 - & $-87.5)$ \\
\hline Slovenia & 2.628 & 95.7( & $94.8-$ & 86.8) & 80.4( & $78.2-$ & 82.6) & 84.0( & $81.8-$ & $-86.2)$ \\
\hline Spain & 3,110 & 96.1( & 95.3- & 96.8) & 84.81 & 83.0 - & 86.2) & 88.1( & $86.8-$ & $-89.6)$ \\
\hline Eastern Europe & 25,556 & 91.51 & 91.1. & 91.9) & 74.31 & 73.6- & 75.1) & 81.21 & $80.5-$ & -82.01 \\
\hline Bulgaria & 2.720 & 78.8( & $77.3-$ & 80.6) & 49.8( & 47.1 - & $52.2)$ & 62.81 & $60.0-$ & - 65.9$)$ \\
\hline Czech Republic & 13,003 & 95.7( & $95.3-$ & 96.1) & 83.4( & $82.4-$ & 84.3) & 87.1( & $86.2-$ & - 88.1) \\
\hline Estonia & 1.023 & 93.8( & 92.1 - & 95.4) & 71.7( & $68.0-$ & 75.5) & 76.5( & $72.8-$ & - 80.3$)$ \\
\hline Latvia & 1,235 & 86.7( & 84.7. & 88.8) & 65.1( & $61.5-$ & 68.8) & $75.0 \mathrm{c}$ & $71.3-$ & $-78.9)$ \\
\hline Lithuania & 1,551 & 88.7( & $86.8-$ & 90.4) & 69.2( & 66.2- & 72.3) & 78.0( & 75.1 & - 81.1) \\
\hline Poland & 2.371 & 84.8( & 83.3. & 86.3) & 61.5( & 59.0 - & 64.1) & 72.8( & $69.8-$ & $-75.3)$ \\
\hline Slovakia & 3.853 & 92.2( & 91.2- & 93.2) & 74.7( & $72.8-$ & 76.7) & 81.1( & $79.2-$ & $83.0)$ \\
\hline Europe & 241,485 & 95.11 & 94.9- & $95.3)$ & 83.21 & 82.9- & 83.6) & 87.51 & 87.2- & - 87.9) \\
\hline
\end{tabular}

\section{Skin Melanoma}

Age-standardized 5-yr relative survival (\%)
Europe, country-weighted age-specific and age-
standardized observed(obs) and relative(rel) survival(\%)

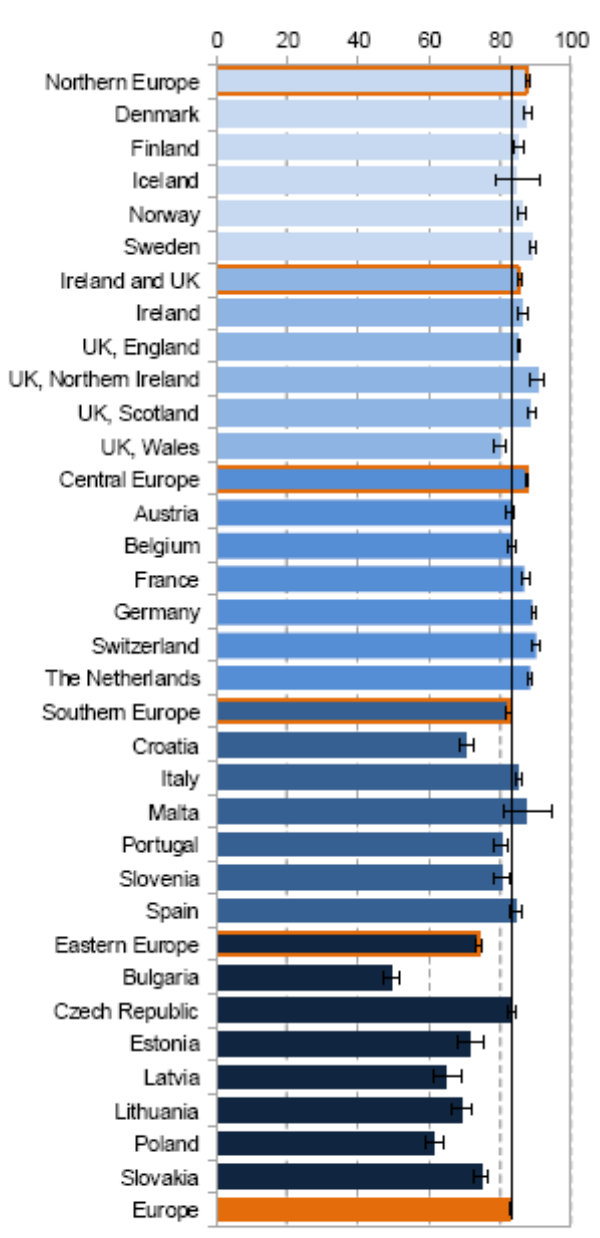

\begin{tabular}{|c|c|c|c|c|c|}
\hline All cases & $\begin{array}{l}\text { Numbers } \\
\text { of cases }\end{array}$ & & $\begin{array}{l}\text { One } \\
\text { year }\end{array}$ & $\begin{array}{l}\text { Three } \\
\text { years }\end{array}$ & $\begin{array}{l}\text { Five } \\
\text { years }\end{array}$ \\
\hline \multirow[t]{2}{*}{$15-44$} & 55,401 & obs & 97.1 & 92.2 & 89.0 \\
\hline & & rel & 97.2 & 92.5 & 89.5 \\
\hline \multirow[t]{2}{*}{$45-54$} & 40,144 & obs & 95.3 & 88.3 & 83.6 \\
\hline & & rel & 95.7 & 89.3 & 85.4 \\
\hline \multirow[t]{2}{*}{ 55-84 } & 48,904 & obs & 94.5 & 85.5 & 79.7 \\
\hline & & rel & 95.3 & 87.9 & 83.6 \\
\hline \multirow[t]{2}{*}{ 85-74 } & 47,849 & obs & 92.5 & 79.4 & 70.8 \\
\hline & & rel & 94.4 & 85.0 & 80.0 \\
\hline \multirow[t]{2}{*}{$75+$} & 48,187 & obs & 83.8 & 80.6 & 46.8 \\
\hline & & rel & 90.8 & 77.6 & 72.0 \\
\hline \multirow[t]{2}{*}{ All adults } & 241.485 & obs & 93.5 & 83.2 & 76.8 \\
\hline & & rel & 95.1 & 87.4 & 83.2 \\
\hline \multicolumn{6}{|l|}{ Male $(46 \%)$} \\
\hline \multirow[t]{2}{*}{$15-44$} & 20,786 & obs & 95.5 & 88.0 & 83.8 \\
\hline & & rel & 95.7 & 88.4 & 84.7 \\
\hline \multirow[t]{2}{*}{$45-54$} & 17.822 & obs & 93.6 & 84.1 & 77.7 \\
\hline & & rel & 94.0 & 85.4 & 80.0 \\
\hline \multirow[t]{2}{*}{ 55-64 } & 25,533 & obs & 92.8 & 81.2 & 74.3 \\
\hline & & rel & 93.8 & 84.3 & 79.4 \\
\hline \multirow[t]{2}{*}{ 85-74 } & 25.534 & obs & 90.8 & 75.4 & 65.5 \\
\hline & & rel & 93.3 & 82.3 & 76.8 \\
\hline \multirow[t]{2}{*}{$75+$} & 21,832 & obs & 83.1 & 57.8 & 42.9 \\
\hline & & rel & 90.8 & 76.6 & 70.2 \\
\hline \multirow[t]{2}{*}{ All adults } & 111,507 & obs & 91.8 & 79.2 & 71.4 \\
\hline & & rel & 93.8 & 84.2 & 79.2 \\
\hline \multicolumn{6}{|c|}{ Female $(54 \%)$} \\
\hline \multirow[t]{2}{*}{$15-44$} & 34,615 & obs & 98.1 & 94.8 & 92.2 \\
\hline & & rel & 98.1 & 25.1 & 92.6 \\
\hline \multirow[t]{2}{*}{ 45-54 } & 22,322 & obs & 96.8 & 91.8 & 88.5 \\
\hline & & rel & 97.1 & 92.6 & 89.8 \\
\hline \multirow[t]{2}{*}{$55-64$} & 24,371 & obs & 96.3 & 89.8 & 85.3 \\
\hline & & rel & 96.8 & 91.5 & 88.0 \\
\hline \multirow[t]{2}{*}{ 85-74 } & 22,315 & obs & 94.3 & 83.8 & 76.5 \\
\hline & & rel & 95.8 & 87.8 & 83.2 \\
\hline \multirow[t]{2}{*}{$75+$} & 26,355 & obs & 84.5 & 62.8 & 48.5 \\
\hline & & rel & 90.7 & 78.6 & 73.4 \\
\hline All adults & 128,978 & obs & 94.8 & 86.6 & 81.0 \\
\hline
\end{tabular}


Figure 2. Age-standardised 5-year relative survival (RS) for cases of both sexes (a.), and men (b.) and women (c.), separately, diagnosed with skin melanoma in 2000-2007, by morphological subgroups and European regions.
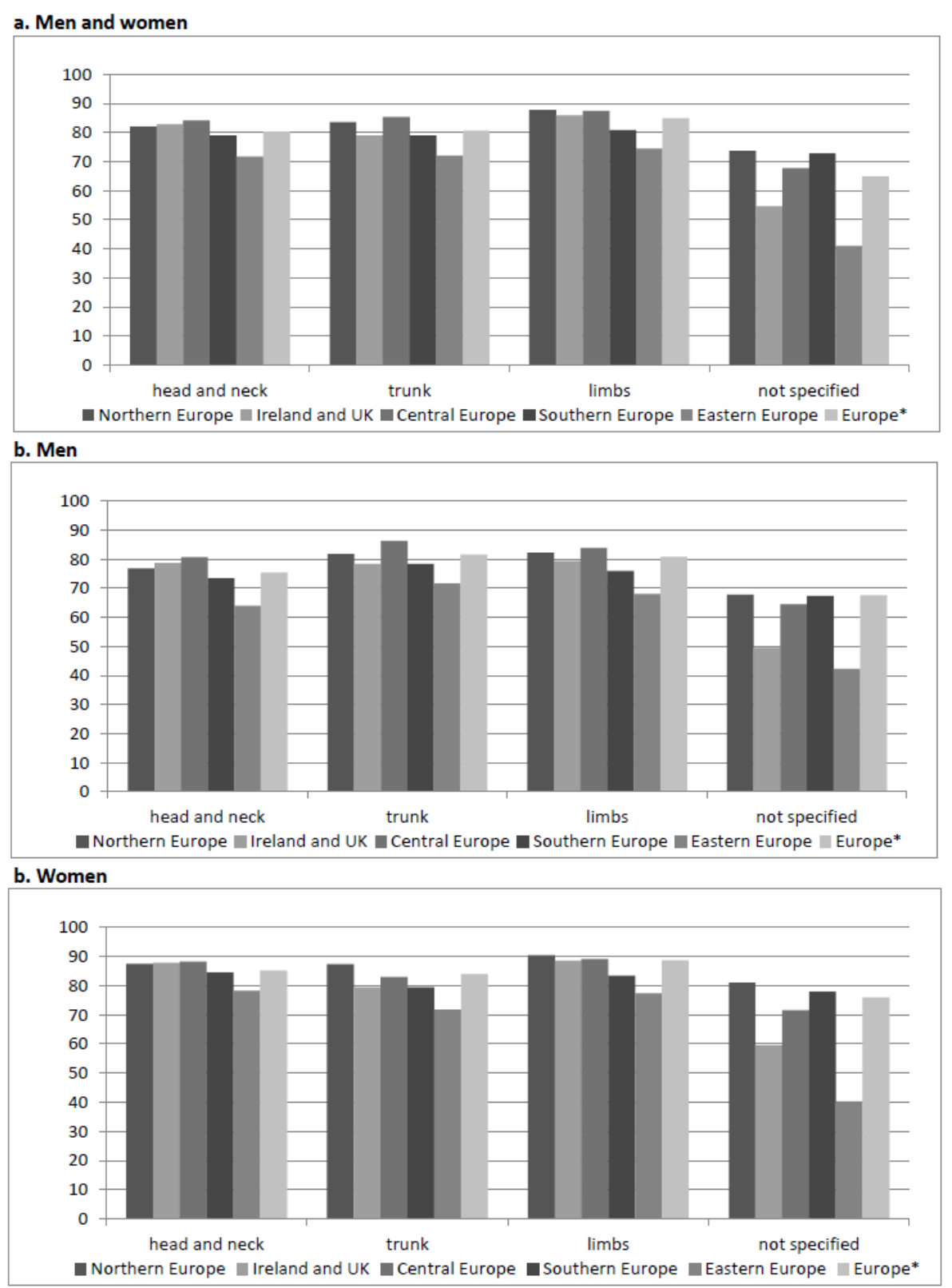

aEstimates are the country-weighted European average (based on countries' average population in 2000-2007). 
Figure 3. Age-standardised 5-year relative survival (RS) for cases of both sexes (a.), and men (b.) and women (c.), separately, diagnosed with skin melanoma in 2000-2007, by subsite and European regions.
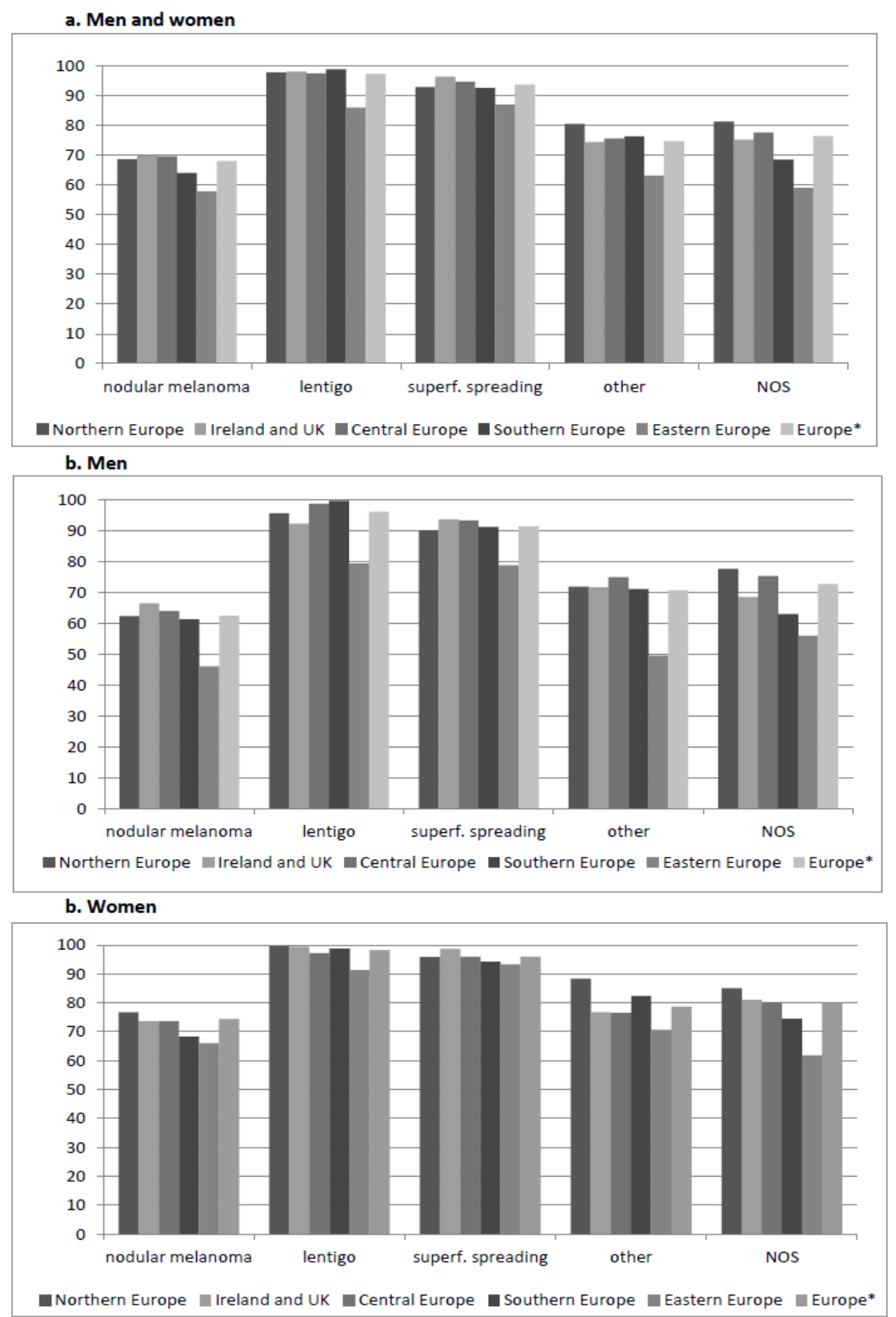

'Estimates are the country-weighted European average (based on countries' average population in 2000-2007). 
Table 1. Quality indicators for skin melanoma cases (2000-2007) and number of cases included in the survival analayses, by registry ${ }^{\mathrm{a}}$, European country and region.

Cases excluded from survival analyses

\begin{tabular}{|c|c|c|c|c|c|c|c|c|c|c|c|c|c|c|}
\hline \multirow[t]{2}{*}{ Cancer registry } & \multirow{2}{*}{$\begin{array}{r}\begin{array}{c}\text { Number } \\
\text { of cases }\end{array} \\
\mathbf{N}\end{array}$} & \multicolumn{2}{|c|}{$\begin{array}{l}\text { Major } \\
\text { errors }\end{array}$} & \multicolumn{2}{|c|}{$\mathbf{D C O}^{\mathbf{a}}$} & \multicolumn{2}{|c|}{ Autopsyb $^{b}$} & \multicolumn{2}{|c|}{$\begin{array}{l}\text { Alive with } \\
\text { zero survival } \\
\text { time }\end{array}$} & \multirow{2}{*}{$\begin{array}{r}\text { Cases eligible for } \\
\text { survival analyses }\end{array}$} & \multicolumn{2}{|c|}{$\begin{array}{l}\text { Microscopically } \\
\text { verified }\end{array}$} & \multicolumn{2}{|c|}{$\begin{array}{l}\text { Unspecified } \\
\text { morphology }\end{array}$} \\
\hline & & $\mathbf{N}$ & $\%$ & $\mathbf{N}$ & $\%$ & & & $\mathbf{N}$ & $\%$ & & $\mathbf{N}$ & $\%$ & $\mathbf{N}$ & $\%$ \\
\hline Northern Europe & 40,642 & 24 & 0.1 & 2 & 0.0 & 15.0 & $\mathbf{0 . 0}$ & 4 & 0.0 & 40597 & 40,435 & 99.6 & 21680 & 53.4 \\
\hline Denmark & 9,657 & 0 & 0.0 & 0 & 0.0 & 3.0 & 0.0 & 0 & 0.0 & 9654 & 9,548 & 98.9 & 9654 & 100.0 \\
\hline Finland & 6,217 & 1 & 0.0 & 1 & 0.0 & 6.0 & 0.1 & 0 & 0.0 & 6209 & 6,197 & 99.8 & 6183 & 99.6 \\
\hline Iceland & 404 & 0 & 0.0 & 0 & 0.0 & 0.0 & 0.0 & 0 & 0.0 & 404 & 403 & 99.8 & 153 & 37.8 \\
\hline Norway & 8,600 & 23 & 0.3 & 1 & 0.0 & 1.0 & 0.0 & 0 & 0.0 & 8575 & 8,532 & 99.5 & 1786 & 20.8 \\
\hline Sweden & 15,764 & 0 & 0.0 & 0 & 0.0 & 5.0 & 0.0 & 4 & 0.0 & 15755 & 15,755 & 100.0 & 3904 & 24.8 \\
\hline Ireland and UK & 76,163 & 12 & $\mathbf{0 . 0}$ & 388 & 0.5 & 1.0 & 0.0 & 1 & 0.0 & 75761 & 73,841 & 97.5 & 27859 & 36.8 \\
\hline Ireland & 4,459 & 1 & 0.0 & 6 & 0.1 & 1.0 & 0.0 & 0 & 0.0 & 4451 & 4,429 & 99.5 & 1807 & 40.6 \\
\hline UK, England & 59,510 & 9 & 0.0 & 346 & 0.6 & 0.0 & 0.0 & 0 & 0.0 & 59155 & 57,735 & 97.6 & 22718 & 38.4 \\
\hline UK, Northern Ireland & 1,824 & 1 & 0.1 & 1 & 0.1 & 0.0 & 0.0 & 0 & 0.0 & 1822 & 1,809 & 99.3 & 287 & 15.7 \\
\hline UK, Scotland & 6,778 & 0 & 0.0 & 3 & 0.0 & 0.0 & 0.0 & 1 & 0.0 & 6774 & 6,754 & 99.7 & 1433 & 21.2 \\
\hline UK, Wales & 3,592 & 1 & 0.0 & 32 & 0.9 & 0.0 & 0.0 & 0 & 0.0 & 3559 & 3,114 & 87.5 & 1614 & 45.4 \\
\hline Central Europe & 69,812 & 2 & 0.0 & 374 & 0.5 & 4.0 & 0.0 & 667 & 1.0 & 68765 & 68,085 & 99.0 & 19261 & 28.0 \\
\hline Austria & 8,545 & 2 & 0.0 & 0 & 0.0 & 0.0 & 0.0 & 0 & 0.0 & 8543 & 8,423 & 98.6 & 5269 & 61.7 \\
\hline Belgium & 6,387 & 0 & 0.0 & 0 & 0.0 & 0.0 & 0.0 & 185 & 2.9 & 6202 & 6,159 & 99.3 & 2559 & 41.3 \\
\hline France & 4,648 & 0 & 0.0 & 0 & 0.0 & 0.0 & 0.0 & 356 & 7.7 & 4292 & 4,284 & 99.8 & 615 & 14.3 \\
\hline Bas Rhin & 754 & 0 & 0.0 & 0 & 0.0 & 0.0 & 0.0 & 9 & 1.2 & 745 & 743 & 99.7 & 169 & 22.7 \\
\hline Calvados & 321 & 0 & 0.0 & 0 & 0.0 & 0.0 & 0.0 & 11 & 3.4 & 310 & 309 & 99.7 & 50 & 16.2 \\
\hline Doubs & 282 & 0 & 0.0 & 0 & 0.0 & 0.0 & 0.0 & 5 & 1.8 & 277 & 277 & 100.0 & 17 & 6.0 \\
\hline Herault & 513 & 0 & 0.0 & 0 & 0.0 & 0.0 & 0.0 & 23 & 4.5 & 490 & 490 & 100.0 & 66 & 13.5 \\
\hline Isere & 667 & 0 & 0.0 & 0 & 0.0 & 0.0 & 0.0 & 78 & 11.7 & 589 & 589 & 100.0 & 42 & 7.0 \\
\hline Loire Atlantique $^{\mathrm{e}}$ & 1,352 & 0 & 0.0 & 0 & 0.0 & 0.0 & 0.0 & 190 & 14.1 & 1162 & 1,160 & 99.8 & 187 & 16.1 \\
\hline
\end{tabular}




\begin{tabular}{|c|c|c|c|c|c|c|c|c|c|c|c|c|c|c|}
\hline Manche & 283 & 0 & 0.0 & 0 & 0.0 & 0.0 & 0.0 & 29 & 10.2 & 254 & 254 & 100.0 & 33 & 13.1 \\
\hline Somme & 262 & 0 & 0.0 & 0 & 0.0 & 0.0 & 0.0 & 10 & 3.8 & 252 & 249 & 98.9 & 33 & 13.0 \\
\hline Tarn & 214 & 0 & 0.0 & 0 & 0.0 & 0.0 & 0.0 & 1 & 0.5 & 213 & 213 & 100.0 & 18 & 8.4 \\
\hline Germany & 21,491 & 0 & 0.0 & 370 & 1.7 & 1.0 & 0.0 & 77 & 0.4 & 21043 & 20543 & 97.6 & 5859 & 27.8 \\
\hline Brandeburg & 2,574 & 0 & 0.0 & 56 & 2.2 & 0.0 & 0.0 & 0 & 0.0 & 2518 & 2,445 & 97.1 & 839 & 33.3 \\
\hline Bremen & 820 & 0 & 0.0 & 20 & 2.4 & 0.0 & 0.0 & 1 & 0.1 & 799 & 777 & 97.2 & 244 & 30.5 \\
\hline $\begin{array}{l}\text { Hamburg } \\
\text { Mecklenburg- }\end{array}$ & 2,509 & 0 & 0.0 & 34 & 1.4 & 0.0 & 0.0 & 1 & 0.0 & 2474 & 2,410 & 97.4 & 1602 & 64.8 \\
\hline Vorpommern & 1,704 & 0 & 0.0 & 46 & 2.7 & 0.0 & 0.0 & 0 & 0.0 & 1658 & 1,610 & 97.1 & 406 & 24.5 \\
\hline Munich & 4,532 & 0 & 0.0 & 12 & 0.3 & 0.0 & 0.0 & 75 & 1.7 & 4445 & 4,445 & 100.0 & 607 & 13.7 \\
\hline Northrhine Westfalia & 2,973 & 0 & 0.0 & 58 & 2.0 & 1.0 & 0.0 & 0 & 0.0 & 2914 & 2,771 & 95.1 & 816 & 28.0 \\
\hline Saarland & 1,264 & 0 & 0.0 & 16 & 1.3 & 0.0 & 0.0 & 0 & 0.0 & 1248 & 1,228 & 98.4 & 364 & 29.2 \\
\hline Saxony & 5,115 & 0 & 0.0 & 128 & 2.5 & 0.0 & 0.0 & 0 & 0.0 & 4987 & 4,857 & 97.4 & 981 & 19.7 \\
\hline Switzerland & 4,185 & 0 & 0.0 & 4 & 0.1 & 3.0 & 0.1 & 47 & 1.1 & 4131 & 4,122 & 99.8 & 779 & 18.9 \\
\hline Basel & 812 & 0 & 0.0 & 3 & 0.4 & 1.0 & 0.1 & 47 & 5.8 & 761 & 756 & 99.3 & 73 & 9.6 \\
\hline Geneva & 995 & 0 & 0.0 & 1 & 0.1 & 2.0 & 0.2 & 0 & 0.0 & 992 & 989 & 99.7 & 215 & 21.7 \\
\hline Grisons & 374 & 0 & 0.0 & 0 & 0.0 & 0.0 & 0.0 & 0 & 0.0 & 374 & 374 & 100.0 & 65 & 17.4 \\
\hline St. Gallen & 820 & 0 & 0.0 & 0 & 0.0 & 0.0 & 0.0 & 0 & 0.0 & 820 & 820 & 100.0 & 180 & 22.0 \\
\hline Ticino & 667 & 0 & 0.0 & 0 & 0.0 & 0.0 & 0.0 & 0 & 0.0 & 667 & 666 & 99.9 & 179 & 26.8 \\
\hline Valais & 517 & 0 & 0.0 & 0 & 0.0 & 0.0 & 0.0 & 0 & 0.0 & 517 & 517 & 100.0 & 67 & 12.9 \\
\hline The Netherlands & 24,556 & 0 & 0.0 & 0 & 0.0 & 0.0 & 0.0 & 2 & 0.0 & 24554 & 24,554 & 100.0 & 4180 & 17.0 \\
\hline Southern Europe & 31,008 & 58 & 0.2 & 45 & 0.1 & 1.0 & 0.0 & 98 & 0.3 & 30806 & 30,440 & 98.8 & 13337 & 43.3 \\
\hline Croatia & 3,812 & 0 & 0.0 & 0 & 0.0 & 0.0 & 0.0 & 0 & 0.0 & 3812 & 3,808 & 99.9 & 3689 & 96.8 \\
\hline Italy & 17,849 & 1 & 0.0 & 27 & 0.2 & 0.0 & 0.0 & 8 & 0.0 & 17813 & 17,521 & 98.4 & 5415 & 30.4 \\
\hline Alto Adige & 578 & 0 & 0.0 & 0 & 0.0 & 0.0 & 0.0 & 0 & 0.0 & 578 & 576 & 99.7 & 38 & 6.6 \\
\hline Biella & 212 & 0 & 0.0 & 1 & 0.5 & 0.0 & 0.0 & 0 & 0.0 & 211 & 210 & 99.5 & 12 & 5.7 \\
\hline Catanzaro & 49 & 0 & 0.0 & 0 & 0.0 & 0.0 & 0.0 & 0 & 0.0 & 49 & 49 & 100.0 & 6 & 12.2 \\
\hline Ferrara & 384 & 0 & 0.0 & 0 & 0.0 & 0.0 & 0.0 & 0 & 0.0 & 384 & 383 & 99.7 & 80 & 20.8 \\
\hline Firenze-Prato & 1,240 & 0 & 0.0 & 1 & 0.1 & 0.0 & 0.0 & 1 & 0.1 & 1238 & 1,181 & 95.4 & 198 & 16.0 \\
\hline Friuli Venezia Giulia & 1,882 & 0 & 0.0 & 0 & 0.0 & 0.0 & 0.0 & 0 & 0.0 & 1882 & 1,882 & 100.0 & 770 & 40.9 \\
\hline
\end{tabular}




\begin{tabular}{|c|c|c|c|c|c|c|c|c|c|c|c|c|c|c|}
\hline Genova & 788 & 0 & 0.0 & 5 & 0.6 & 0.0 & 0.0 & 0 & 0.0 & 783 & 762 & 97.3 & 126 & 16.1 \\
\hline Latina & 510 & 0 & 0.0 & 6 & 1.2 & 0.0 & 0.0 & 1 & 0.2 & 503 & 443 & 88.0 & 158 & 31.4 \\
\hline Mantova & 223 & 0 & 0.0 & 0 & 0.0 & 0.0 & 0.0 & 0 & 0.0 & 223 & 222 & 99.6 & 136 & 61.0 \\
\hline Milano & 1,694 & 0 & 0.0 & 0 & 0.0 & 0.0 & 0.0 & 3 & 0.2 & 1691 & 1,689 & 99.9 & 358 & 21.2 \\
\hline Modena & 697 & 0 & 0.0 & 0 & 0.0 & 0.0 & 0.0 & 0 & 0.0 & 697 & 697 & 100.0 & 130 & 18.7 \\
\hline Napoli & 233 & 0 & 0.0 & 0 & 0.0 & 0.0 & 0.0 & 1 & 0.4 & 232 & 231 & 99.6 & 65 & 27.9 \\
\hline Nuoro & 25 & 0 & 0.0 & 0 & 0.0 & 0.0 & 0.0 & 0 & 0.0 & 25 & 25 & 100.0 & 10 & 40.0 \\
\hline Palermo & 350 & 0 & 0.0 & 3 & 0.9 & 0.0 & 0.0 & 0 & 0.0 & 347 & 308 & 88.9 & 95 & 27.4 \\
\hline Parma & 542 & 0 & 0.0 & 0 & 0.0 & 0.0 & 0.0 & 0 & 0.0 & 542 & 542 & 100.0 & 53 & 9.8 \\
\hline Ragusa & 173 & 0 & 0.0 & 1 & 0.6 & 0.0 & 0.0 & 0 & 0.0 & 172 & 167 & 97.1 & 34 & 19.7 \\
\hline Reggio Emilia & 478 & 0 & 0.0 & 0 & 0.0 & 0.0 & 0.0 & 0 & 0.0 & 478 & 473 & 99.0 & 290 & 60.7 \\
\hline Romagna & 1,556 & 0 & 0.0 & 2 & 0.1 & 0.0 & 0.0 & 0 & 0.0 & 1554 & 1,535 & 98.8 & 233 & 15.0 \\
\hline Salerno & 497 & 0 & 0.0 & 3 & 0.6 & 0.0 & 0.0 & 2 & 0.4 & 492 & 474 & 96.4 & 186 & 37.8 \\
\hline Sassari & 180 & 0 & 0.0 & 1 & 0.6 & 0.0 & 0.0 & 0 & 0.0 & 179 & 175 & 97.8 & 54 & 30.0 \\
\hline Siracusa & 206 & 0 & 0.0 & 1 & 0.5 & 0.0 & 0.0 & 0 & 0.0 & 205 & 200 & 97.6 & 29 & 14.1 \\
\hline Sondrio & 179 & 0 & 0.0 & 0 & 0.0 & 0.0 & 0.0 & 0 & 0.0 & 179 & 178 & 99.4 & 28 & 15.6 \\
\hline Torino & 1,179 & 1 & 0.1 & 0 & 0.0 & 0.0 & 0.0 & 0 & 0.0 & 1178 & 1,174 & 99.7 & 305 & 25.9 \\
\hline Trapani & 124 & 0 & 0.0 & 0 & 0.0 & 0.0 & 0.0 & 0 & 0.0 & 124 & 123 & 99.2 & 11 & 8.9 \\
\hline Trentino & 402 & 0 & 0.0 & 0 & 0.0 & 0.0 & 0.0 & 0 & 0.0 & 402 & 402 & 100.0 & 103 & 25.6 \\
\hline Umbria & 815 & 0 & 0.0 & 0 & 0.0 & 0.0 & 0.0 & 0 & 0.0 & 815 & 811 & 99.5 & 234 & 28.7 \\
\hline Varese & 577 & 0 & 0.0 & 0 & 0.0 & 0.0 & 0.0 & 0 & 0.0 & 577 & 571 & 99.0 & 123 & 21.3 \\
\hline Veneto & 2,076 & 0 & 0.0 & 3 & 0.1 & 0.0 & 0.0 & 0 & 0.0 & 2073 & 2,038 & 98.3 & 1550 & 74.8 \\
\hline Malta & 280 & 1 & 0.4 & 3 & 1.1 & 0.0 & 0.0 & 1 & 0.4 & 275 & 266 & 96.8 & 108 & 39.3 \\
\hline tugal & 3257 & 55 & 1.7 & 1 & 0.0 & 0.0 & 0.0 & 33 & 1.0 & 3168 & 3134 & 98.9 & 2305 & 72.8 \\
\hline Açores & 84 & 0 & 0.0 & 1 & 1.2 & 0.0 & 0.0 & 2 & 2.4 & 81 & 80 & 98.8 & 60 & 73.8 \\
\hline Northern Portugal & 1,065 & 0 & 0.0 & 0 & 0.0 & 0.0 & 0.0 & 18 & 1.7 & 1047 & 1,047 & 100.0 & 733 & 70.0 \\
\hline Southern Portugal & 2,108 & 55 & 2.6 & 0 & 0.0 & 0.0 & 0.0 & 13 & 0.6 & 2040 & 2,007 & 98.4 & 1512 & 74.1 \\
\hline venia National & 2,629 & 0 & 0.0 & 0 & 0.0 & 1.0 & 0.0 & 0 & 0.0 & 2628 & 2,628 & 100.0 & 890 & 33.9 \\
\hline in & 3,181 & 1 & 0.0 & 14 & 0.4 & 0.0 & 0.0 & 56 & 1.8 & 3110 & 3083 & 99.1 & 930 & 29.9 \\
\hline Basque Country & 1,067 & 0 & 0.0 & 6 & 0.6 & 0.0 & 0.0 & 11 & 1.0 & 1050 & 1,044 & 99.4 & 378 & 36.0 \\
\hline
\end{tabular}




\begin{tabular}{|c|c|c|c|c|c|c|c|c|c|c|c|c|c|c|}
\hline Cuenca & 62 & 0 & 0.0 & 0 & 0.0 & 0.0 & 0.0 & 0 & 0.0 & 62 & 62 & 100.0 & 15 & 24.2 \\
\hline Girona & 409 & 1 & 0.2 & 2 & 0.5 & 0.0 & 0.0 & 8 & 2.0 & 398 & 393 & 98.8 & 60 & 15.0 \\
\hline Granada & 408 & 0 & 0.0 & 0 & 0.0 & 0.0 & 0.0 & 0 & 0.0 & 408 & 404 & 99.0 & 71 & 17.4 \\
\hline Murcia & 450 & 0 & 0.0 & 2 & 0.4 & 0.0 & 0.0 & 37 & 8.2 & 411 & 406 & 98.7 & 81 & 19.8 \\
\hline Navarra & 397 & 0 & 0.0 & 1 & 0.3 & 0.0 & 0.0 & 0 & 0.0 & 396 & 394 & 99.5 & 132 & 33.2 \\
\hline Tarragona & 388 & 0 & 0.0 & 3 & 0.8 & 0.0 & 0.0 & 0 & 0.0 & 385 & 380 & 98.7 & 193 & 50.0 \\
\hline Eastern Europe & 25,792 & 31 & 0.1 & 97 & 0.4 & 80.0 & 0.3 & 28 & 0.1 & 25556 & 25,174 & 98.5 & 11540 & 45.2 \\
\hline Bulgaria & 2,722 & 0 & 0.0 & 2 & 0.1 & 0.0 & 0.0 & 0 & 0.0 & 2720 & 2,717 & 99.9 & 2106 & 77.4 \\
\hline Czech Republic & 13,087 & 0 & 0.0 & 0 & 0.0 & 70.0 & 0.5 & 14 & 0.1 & 13003 & 13,003 & 100.0 & 4238 & 32.6 \\
\hline Estonia & 1,027 & 0 & 0.0 & 2 & 0.2 & 2.0 & 0.2 & 0 & 0.0 & 1023 & 1,014 & 99.1 & 214 & 21.0 \\
\hline Latvia & 1,265 & 4 & 0.3 & 21 & 1.7 & 5.0 & 0.4 & 0 & 0.0 & 1235 & 1,182 & 95.7 & 671 & 54.3 \\
\hline Lithuania & 1,554 & 0 & 0.0 & 1 & 0.1 & 0.0 & 0.0 & 2 & 0.1 & 1551 & 1,549 & 99.9 & 1208 & 77.9 \\
\hline Poland & 2,496 & 27 & 1.1 & 2 & 0.1 & 1.0 & 0.0 & 14 & 0.6 & 2452 & 2,282 & 93.1 & 2145 & 87.5 \\
\hline Cracow & 522 & 27 & 5.2 & 0 & 0.0 & 1.0 & 0.2 & 5 & 1.0 & 489 & 489 & 100.0 & 458 & 93.7 \\
\hline Kielce & 623 & 0 & 0.0 & 1 & 0.2 & 0.0 & 0.0 & 0 & 0.0 & 622 & 622 & 100.0 & 440 & 70.8 \\
\hline Silesia & 1,267 & 0 & 0.0 & 0 & 0.0 & 0.0 & 0.0 & 7 & 0.6 & 1260 & 1,171 & 92.9 & 1247 & 99.0 \\
\hline Slovakia & 3,725 & 0 & 0.0 & 70 & 1.9 & 2.0 & 0.1 & 0 & 0.0 & 3653 & 3,427 & 93.8 & 958 & 26.2 \\
\hline Europe & 243,417 & 127 & 0.1 & 906 & 0.4 & 101.0 & 0.0 & 798 & 0.3 & 241485 & 237,975 & 98.5 & 93213 & 38.6 \\
\hline
\end{tabular}

${ }^{a}$ Data from European 86 cancer registries

${ }^{\mathrm{b}}$ Cases known by death certificate

${ }^{\mathrm{c}}$ Diagnosed incidentally at autopsy

${ }^{d}$ Proportion of patients diagnosed while alive in 2000-03, censored with less than 5 years of follow-up. For the French registries this quality indicator was calculated for cases diagnosed in 2000-02

${ }^{\mathrm{e}}$ Morphology not otherwise specified

${ }^{\mathrm{f}}$ Specialised cancer registry till 1997

Table 2. Distribution of topography $\mathrm{y}^{\mathrm{a}}$ and morphology $\mathrm{y}^{\mathrm{b}}$ subgroups for skin melanoma cases diagnosed in 2000-2007, overall and by European region. 


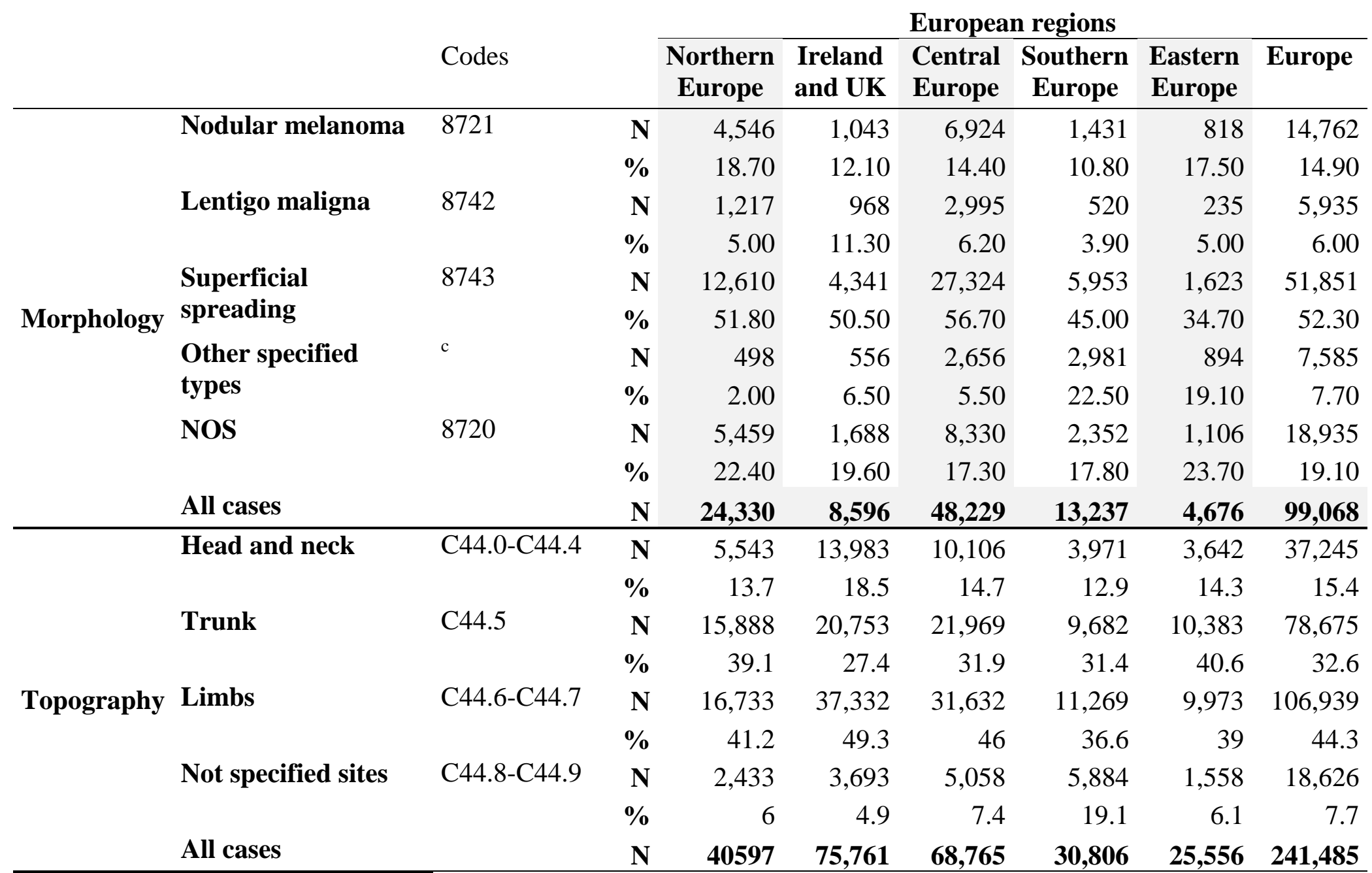

${ }^{\mathrm{a}}$ Data from 86 European cancer registries (CRs); ${ }^{\mathrm{b}}$ Data from 51/86 CRs with adequate information on morphology (arbitrarily defined as <30\% not otherwise specified [NOS] morphology codes 8720); ${ }^{c}$ Comprising the following morphology codes: 8722-3, 8730, 8740-1, 8744-6, 8761, 8770-4, 8780 